\title{
The European Arrest Warrant: Latvian Experience of Application
}

\author{
Jelena Groma \\ Mag. iur. Riga Stradins University \\ Faculty of Law \\ E-mail: Jelena.groma@inbox.Iv \\ Sandra Kaija \\ Dr. iur., Prof. Baltic International Academy \\ Faculty of Law \\ E-mail: skazaka@inbox.lv
}

\section{Doi:10.5901/mjss.2013.v4n11p310}

\begin{abstract}
The European arrest warrant (EAW) is a request by a judicial authority in one of the Member States of the EU to arrest a person in another Member State and to surrender that person to the former state for the purpose of prosecuting or executing a custodial sentence or detention order. It was adopted by the Council of the European Union on 13 June 2002. EAW is based on the principle of mutual recognition to foreign judicial decisions and judgments in criminal matters, simplifies and speeds up the procedure of extradition. The EAW ensures a good balance between efficiency and strict guarantees that the arrested person's fundamental rights are respected. EAW introduced innovative elements as compared with traditional extradition procedure: strict time limits, simpler procedures, no political involvement, surrender of nationals, guarantees, and grounds for refusal. EAW has been adopted along with the Criminal Procedure Law of Republic of Latvia on 1 October 2005. This paper comments on implementation of the EAW in the EU Member States and features some aspects of Latvian experience.
\end{abstract}

Keywords. The European arrest warrant, European Union, implementation of EAW

\section{Introduction}

The EAW adopted in 2002 has replaced the traditional extradition system with a simpler instrument of surrender of requested persons for the purposes of conducting a criminal prosecution or executing a custodial sentence or detention order. As the first measure applying the principle of mutual recognition to foreign judicial decisions and judgments in criminal matters, it has been a key development in the creation of a European Area of Freedom, Security and Justice. The success of the European Union's mutual recognition program hinges on the existence of genuine trust between Member States, and especially between all actors in the criminal justice process.

According to the Conclusions of the Tampere European Council of 15 and 16 October 1999, and in particular point 35 thereof, the formal extradition procedure was abolished among the Member States in respect of persons who are fleeing from justice after having been finally sentenced and extradition procedures were speeded up in respect of persons suspected of having committed an offence. On 13 June 2002 the Council adopted the Framework Decision on the European arrest warrant (2002/584/JHA: Council Framework Decision of 13 June 2002 on the European arrest warrant), and the framework decision entered into force on 1 January 2004 replacing the existing conventions in this area: the European Convention on Extradition of 13 December 1957, its additional protocol of 15 October 1975, its second additional protocol of 17 March 1978, and the European Convention on the suppression of terrorism of 27 January 1977 as far as extradition is concerned; the Agreement between the 12 Member States of the European Communities on the simplification and modernization of methods of transmitting extradition requests of 26 May 1989; the Convention of 10 March 1995 on simplified extradition procedure between the Member States of the European Union; the Convention of 27 September 1996 relating to extradition between the Member States of the European Union; Title III, Chapter 4 of the Convention of 19 June 1990 implementing the Schengen Agreement of 14 June 1985 on the gradual abolition of checks at common borders.

The Framework Decision on the Arrest Warrant and surrender procedures between Member States introduced a cooperation mechanism of a strictly judicial nature, which permitted the practical-administrative assistance among 
Member State executive bodies, thus leading to the free circulation of criminal decisions, grounded on a system of mutual trust among the Member States' legal systems (Pollicino, 2008).

The offences giving rise to surrender pursuant to the EAW and listed in the Framework Decision 2002/584/JHA Art. 2(2) include, inter alia: participation in a criminal organization, terrorism, corruption, forgery of means of payment, sexual exploitation of children and child pornography, illicit trafficking in narcotic drugs and psychotropic substances, murder, grievous bodily injury, counterfeiting and piracy of products.

It is important to state that the EAW was the first legal instrument based upon mutual recognition of decisions in criminal matters. It changed the old system of extradition, which has been replaced by a system of surrender within an area of freedom, security and justice. Today, the EU offers its citizens an area without internal borders, within which the free movement of persons is guaranteed, coupled with corresponding measures in the area of external border controls, asylum and immigration policy, and preventing and fighting crime. This concept was introduced in reflection of the view that the tasks of maintaining public order, internal peace and security are distributed between the member states and the European Union (Klimek, 2012).

The Criminal procedure law of Republic of Latvia (21.04.2005. likums "Kriminālprocesa likums") has been adopted on the $21^{\text {st }}$ of April 2005, and the legal basis related to the EAW can be obtained from the chapters 65 - "Extradition of a person to Latvia" and 66 - "Extradition of a person to a foreign State", within division fourteen - "Extradition", part C "International Cooperation in criminal matters" of the Criminal procedure Law (CPL), namely Sections 691-695 (concerning cases in which Latvia acts as issuing State) and 714-722 (concerning cases in which Latvia acts as executing State).

Experts with substantial practical knowledge of the EAW were nominated by Member States pursuant to a written request to delegations made by the Chairman of the MDG on 9 September 2005. At its meeting on 28 October 2005 the MDG approved the evaluation questionnaire for the fourth round of mutual evaluations. The objectives of the evaluation exercise and the questionnaire itself are set out in ST 14272/05 CRIMORG 131 COPEN 175 EJN 57 EUROJUST 77. The expert team with the assistance of the Council Secretariat, based on their findings arising from the evaluation visit of 20-22 May 2008, provided recommendations by which the EAW and its corresponding surrender provisions may be further streamlined and improved. This paper reports on implementation of the EAW in the EU Member States and includes some remarks on Latvian experience.

\section{General principles of the EAW}

The EAW is a judicial decision enforceable in the European Union, issued by a Member State and executed in another Member State on the basis of the principle of mutual recognition. The decision simplifies and speeds up the procedures, given that the whole political and administrative phase is replaced by a judicial mechanism. The EAW is issued by a Member State with a view to the arrest or surrender by another Member State of a requested person, for the purposes of conducting a criminal prosecution; executing a custodial sentence; executing a detention order.

The innovative features of the EAW are attributed to: its judicial nature; partial abolition of double criminality check with reference to the thirty two offences listed, i.e., the rule that an offence must be punishable both in the country, where the requested person is located and in the country issuing the warrant; simplification and acceleration of the surrender procedures; surrender of the requested person under the principle of mutual recognition and mutual trust; independence of the requested person's surrender from his/her nationality and politics (Gilmore, 2002 ; Pérignon and Daucé, 2007; Bednarek, 2009; Campana, 2013).

A warrant is applied for purposes of criminal prosecution in relation to acts punishable under domestic law by a custodial sentence or detention order for a maximum period of at least 12 months (during the investigation, examining and trial stages, until the conviction is final) or for execution of a sentence or detention order of at least 4 months.

If they are punishable in the issuing Member State by a custodial sentence of at least three years, the following offences, among others, may give rise to surrender without verification of the double criminality of the act: terrorism, trafficking in human beings, corruption, participation in a criminal organization, counterfeiting currency, murder, racism and xenophobia, rape, trafficking in stolen vehicles, and fraud, including that affecting the financial interests of the Communities. For criminal acts other than those mentioned above, surrender may be subject to the condition that the act for which surrender is requested constitutes an offence under the law of the executing Member State (double criminality rule).

It is stated that the EAW must contain information on the identity of the person concerned, the issuing judicial authority, the final judgment, the nature of the offence, the penalty, etc. (a specimen form is attached to the framework 
decision, (17195/1/10 REV 1: European handbook on how to issue a European arrest warrant).

\section{Implementation of the European Arrest Warrant in the EU Member States}

The implementation of the EAW was the subject of a first evaluation in 2005. This concluded on a positive note though the EAW was still in an experimental phase (Pérignon and Daucé, 2007). The number of EAWs issued for the year 2005 was more than 6900 and represented more than a doubling compared to 2004, resulting in the identification and arrest of more than 1770 persons, 1532 of whom have effectively been surrendered.

It has been mentioned in the Report made by the commission to the European Parliament and the Council (On the implementation since 2007 of the Council Framework Decision of 13 June 2002 on the European arrest warrant and the surrender procedures between Member States $\{\operatorname{SEC}(2011) 430$ final) on the 11 th of April 2011 that a number of issued and executed EAWs for the years between 2005 and 2009 is exposed as follows 54689 and 11 630, accordingly. During that period between $51 \%$ and $62 \%$ of requested persons consented to their surrender, on average within 14 to 17 days. The average surrender time for those who did not consent was 48 days. This contrasts very favorably with the pre-EAW position of a one-year average for the extradition of requested persons and has undoubtedly reinforced the free movement of persons within the EU by providing a more efficient mechanism to ensure that open borders are not exploited by those seeking to evade justice.

Continuing analysis of the above mentioned Report (On the implementation since 2007 of the Council Framework Decision of 13 June 2002 on the European arrest warrant and the surrender procedures between Member States \{SEC(2011) 430 final), one can find that, despite the fact that the law and criminal procedures of all Member States are subject to the standards of the European Court of Human Rights, there are often some doubts about standards being similar across the EU. While an individual can have recourse to the European Court of Human Rights to assert rights arising from the European Convention on Human Rights, this can only be done after an alleged breach has occurred and all domestic legal avenues have been exhausted. This has not proved to be an effective means of ensuring that signatories comply with the Convention's standards. This situation has informed the Commission's ongoing work on the implementation of the roadmap for strengthening the procedural rights of suspected or accused persons in criminal proceedings. This roadmap, adopted by the Council on 30 November 2009, recognizes in Recital 10 that "a lot of progress has been made in the area of judicial and police cooperation on measures that facilitate prosecution. It is now time to take action to improve the balance between these measures and the protection of procedural rights of the individual". While retaining the possibility of adding other rights, the roadmap identifies the following six priority measures: the right to interpretation and translation; the right to information about rights (Letter of Rights); pre-trial legal advice and at-trial legal aid; a detained person's right to communicate with family members, employers and consular authorities; protection for vulnerable suspects; a green paper on pre-trial detention.

Moreover, the above mentioned Report (On the implementation since 2007 of the Council Framework Decision of 13 June 2002 on the European arrest warrant and the surrender procedures between Member States (SEC(2011) 430 final) suggests that protection of fundamental rights in particular must be central to the operation of the EAW system. Action is required in the following areas: 1) transposition: Member States should take legislative action, where required, to address the areas where their implementing legislation fails to comply with the Council Framework Decision on the EAW; 2) fundamental rights: there must be adoption and implementation of the measures arising from the roadmap on procedural rights for suspects and accused persons to ensure that fundamental rights and freedoms are protected and to improve the mutual trust that is essential to the continued operation of mutual recognition instruments such as the Council Framework Decision on the EAW; 3) proportionality: judicial authorities should use the EAW system only when a surrender request is proportionate in all the circumstances of the case and should apply a proportionality test in a uniform way across Member States. Member States must take positive steps to ensure that practitioners use the amended handbook (in conjunction with their respective statutory provisions, if any) as the guideline for the manner in which a proportionality test should be applied; 4) training: the Commission communication planned for September 2011 on European judicial training is intended to address the need for specific training for both judicial authorities and legal practitioners on the implementation of the EAW and on the new measures for strengthening procedural rights for suspects and accused persons. Training for judicial authorities is essential to ensure consistency in issues such as the application of a proportionality test across Member States. The Commission notes that the European Judicial Network will launch a new website in 2011, which will provide a useful tool to ensure that judicial authorities have access to appropriate information on the EAW; 5) implementation of complementary instruments: a considerable amount of work has been done since 2004 on identifying problems and improving the EAW system. There have been four Council 
Framework Decisions that affect the operation of the EAW. These measures address the issues of transfer of sentences, in absentia judgments, conflicts of jurisdiction and recognition of supervision orders. Their expeditious implementation by Member States in the near future may further improve the practical operation of the EAW; 6) statistics: we now have several years of statistical data based on replies to the questionnaire devised by the Council Working Party on Cooperation on Criminal Matters in April 2005. Thereafter, replies to the questionnaire have been collated and published for years 2005 to 2009 inclusive. However, as the report states, there are considerable shortcomings in the statistical data available for analysis. There are a number of reasons for this. Not all Member States have provided data systematically and Member States do not share a common statistical tool. Moreover, different interpretations are to be found in the answers to the Council's yearly questionnaire. There is also evidence of underreporting to Eurojust of breaches of the time limits in the Council Framework Decision, despite the obligation to report in Article 17. The Commission urges Member States to meet their obligation to report. Comprehensive statistics are essential for a proper evaluation of both the successes and shortcomings of the EAW. It is imperative that Member States provide full statistical data, especially those which have not done so to date. The Commission will make every effort to address the shortcomings in the questionnaire on EAW statistics and will look at ways of improving the collection of statistics.

The Framework Decision contains some serious flaws related to the simultaneous restriction of the nationality exception and the dual criminality rule. Whereas it was suggested above that implementing acts could eliminate some of these flaws, it rather appears that those statutes will create as much controversy as they solve (Deen-Racsmany, Blekxtoon, 2005).

As it has been stated in evaluation Report on the fourth round of mutual evaluations hold in May 2008 (17220/08: Evaluation report on the fourth round of mutual evaluations), Latvia has decided to transpose the Framework Decision into its national law by inserting several provisions into the Criminal Procedure Law, namely in part C - "International Cooperation in criminal matters", division fourteen - "Extradition", chapters 65 -"Extradition of a person to Latvia" and 66 "Extradition of a person to a foreign State". As a result of this, the provisions regarding EAW procedures were mixed with the provisions on extradition procedures. Furthermore, the provisions concerning EAW procedures were in general given as an exception to the general rules on extradition, although the EAW has abolished extradition among Member States.

As it appears to be documented in the appendices of the Report On the operation of the European Arrest Warrant Act 2003 (as amended) in the year 2012 made to the Houses of the Oireachtas by the Central Authority in the person of the Minister for Justice and Equality pursuant to section 6(6) of the European Arrest Warrant Act 2003, developments in the year 2012 in relation to EAW received by the Central Authority, are illustrated as follows - 589 EAWs received between 2004 and 2011 were still ongoing at 1 January 2012. 253 EAWs received between 2004 and 2011 were completed in 2012, of which: surrender order executed in 2012: 125, withdrawn - 87, closed following arrest elsewhere 2, released - 11, endorsement refused -7 , and surrender refused - 21. 359 EAWs were still at various stages of processing at 31 December 2012.

A total of 313 EAWs were received from Member States by the Central Authority in 2012; 170 warrants for Polish nationals, 25 for Irish nationals, 22 for Lithuanian nationals, 34 for UK nationals, 15 for Czech Republic nationals and 8 for Latvian nationals were among those sought on foot of European arrest warrants received in 2012. In all, nationals of 16 countries were sought in this jurisdiction during 2012.

Among the principal offences cited in EAWs received during 2012 were: murder/grievous bodily harm (22), sexual offences including rape and sexual abuse of children (13), drugs offences (34), organized crime/robbery (116), fraud (77), human trafficking (1) (Table 1).

29 persons who were the subjects of European arrest warrants transmitted between 2004 and 2011 were surrendered in 2012, 24 from the UK, one from Poland, one from Spain, one from Slovakia, one from the Czech Republic and one from Lithuania.

\section{Conclusions}

The Framework Decision on the EAW made in 2002 reflected a philosophy of integration in a common judicial area and showed a new pattern of cooperation based upon mutual trust between Member States. The EAW is the first legal instrument based upon mutual recognition of decisions in criminal matters. It implies a radical change from the traditional extradition system, which has been replaced by a system of surrender within an area of freedom, security and justice, with an impact, in particular, on procedures, time limits and grounds for nonsurrender of a person.

The EAW is supposed be used as a tool for the prevention and repression of crime, while safeguarding the human rights of suspects and convicted persons. The EAW has been designed to further the prosecution of more serious or 
more damaging crime which may substantially justify its use, or for purposes of enforcement of convictions. It is only intended to be used if an arrest warrant or any other enforceable judicial decision having the same effect has been issued at national level.

Protection of fundamental rights related to the operation of the EAW system is one of the major statements fixed by commission reports to the European Parliament and the Council.

Latvian implementing legislation is mostly in line with the Framework Decision. However, some divergences can be observed and a number of provisions of the Framework Decision have not been transposed.

\section{References}

Bednarek, G. (2009) Translation of the European Arrest Warrant in the Light of Intercultural Communication. Investigationes Linguisticae, 17, 84-99.

Campana, P. (2013) Understanding Then Responding to Italian Organized Crime Operations across Territories. Policing: A Journal of Policy and Practice, 10.1093/police/pat012.

Deen-Racsmany, Z., Blekxtoon, J.R. (2005). The decline of the nationality exception in European extradition. European Journal of Crime, Criminal Law and Criminal Justice, 13/3, 317-363.

Gilmore, B. (2002) The EU Framework Decision on the European Arrest Warrant: An Overview from the Perspective of International Criminal Law. ERA-Forum, 3, 144-147.

Klimek, L. (2012). European Arrest Warrant: Procedural Instrument for Public Order Enforcement in the EU's Area of Freedom, Security and Justice. In A. J. Belohlavek, \& N. Rozehnalova (Eds.), Czech Yearbook of International Law 2012. (pp. 3-18). Juris Publishing: Huntington, New York.

Pérignon, I., Daucé, C. (2007) The European Arrest Warrant: a Growing Success Story. ERA Academy of European Law, 8, 203-214.

Pollicino, O. (2008). European Arrest Warrant and Constitutional Principles of the Member States: A Case Law-Based Outline in an Attempt to Strike the Right Balance Between Legal Systems - Part I/II, 9. German Law Journal, 9, 1313-1354.

\section{Legal acts}

2002/584/JHA: Council Framework Decision of 13 June 2002 on the European arrest warrant and the surrender procedures between Member States - Statements made by certain Member States on the adoption of the Framework Decision. [Online] Available: http://eur-lex.europa.eu/LexUriServ/LexUriServ.do?uri=CELEX:32002F0584:EN:NOT (June 15, 2013).

17195/1/10 REV 1: European handbook on how to issue a European arrest warrant. [Online] Available: http://register.consilium.europa.eu/pdf/en/10/st17/st17195-re01.en10.pdf (June 16, 2013).

21.04.2005. likums "Kriminālprocesa likums" spēkā no 01.10.2005. publicēts "Latvijas Vēstnesis", 74 (3232), 11.05.2005., "Zingotājs", 11, 09.06.2005. (Criminal procedure law, in latvian).

\section{Reports}

17220/08: Evaluation report on the fourth round of mutual evaluations "The practical application of the European arrest warrant and corresponding surrender procedures between member states" - report on Latvia. [Online] Available: http://www.google.com/search?source=ig\&hl=Iv\&rlz=1G1TSNA_LVLV543\&=\&q=17220\%2F08\%3A+Evaluation+report+on+the+f ourth+round+of+mutual+evaluations+\&oq=17220\%2F08\%3A+Evaluation+report+on+the+fourth+round+of+mutual+evaluations+ \&gs_l=igoogle.3...4193.4193.0.5411.1.1.0.0.0.0.132.132.0j1.1.0...0.0...1ac.2.12.igoogle.Gr1DZaYIEg4 (June 15, 2013).

Report from the Commission to the European Parliament and the Council On the implementation since 2007 of the Council Framework Decision of 13 June 2002 on the European arrest warrant and the surrender procedures between Member States $\{$ SEC(2011) 430 final. [Online] Available: http://eur-lex.europa.eu/LexUriServ/LexUriServ.do?uri=CELEX:52011DC0175:EN:NOT (June 1, 2013).

Report On the operation of the European Arrest Warrant Act 2003 (as amended) in the year 2012 made to the Houses of the Oireachtas by the Central Authority in the person of the Minister for Justice and Equality pursuant to section 6(6) of the European Arrest Warrant Act 2003. [Online] Available: http://www.justice.ie/en/JELR/JUQdoclaid280313.pdf/Files/JUQdoclaid280313.pdf 
Table 1. Classification of European arrest warrants received in 2012 by nature of the principal offence

\begin{tabular}{|c|c|c|c|c|c|c|c|c|c|c|c|c|c|}
\hline Country & $\begin{array}{c}\text { Murder/ } \\
\text { attempted } \\
\text { Murder }\end{array}$ & \begin{tabular}{|c|} 
Terroris \\
$\mathrm{m}$
\end{tabular} & $\begin{array}{c}\text { Sexual } \\
\text { offences }\end{array}$ & \begin{tabular}{|c|} 
Drug \\
offences
\end{tabular} & $\begin{array}{c}\text { Kidnappin } \\
\mathrm{g}\end{array}$ & $\begin{array}{l}\text { Robbery/ } \\
\text { Assault/ } \\
\text { Theft, } \\
\text { Damage } \\
\text { to } \\
\text { Property }\end{array}$ & \begin{tabular}{|c|} 
Racketeeri \\
$n g /$ \\
Participatio \\
$n$ \\
in Criminal \\
Organizatio \\
$n /$ \\
Organized \\
Armed \\
Robbery/M \\
oney \\
Laundering
\end{tabular} & \begin{tabular}{|c|} 
Fraud/ \\
Forgery/ \\
Corruption \\
Swindling/ \\
Computer \\
Crimes
\end{tabular} & \begin{tabular}{|c|} 
Trafficking \\
Weapons/ \\
People/ \\
Documents \\
$I$ \\
Vehicles
\end{tabular} & \begin{tabular}{|c|} 
Traffic \\
Offences
\end{tabular} & \begin{tabular}{|c|} 
Family: \\
Domestic \\
Violence/Child \\
Maintenance
\end{tabular} & \begin{tabular}{|c|} 
Miscell \\
aneous
\end{tabular} & Totals \\
\hline Poland & 3 & & 2 & 23 & 1 & 63 & 16 & 46 & & 6 & 6 & 3 & 169 \\
\hline UK & 14 & 1 & 10 & 1 & & 11 & 4 & 7 & 1 & & & 2 & 51 \\
\hline Lithuania & 1 & & & 5 & & 7 & 1 & 4 & 1 & & & 2 & 21 \\
\hline Czech Rep & 1 & & & & & 6 & 1 & 7 & & 1 & 1 & 1 & 18 \\
\hline Romania & & & & 1 & & 8 & & 2 & & & 1 & & 12 \\
\hline Latvia & & & 1 & & & 6 & & & & & & 1 & 8 \\
\hline Slovakia & & & & 1 & & 2 & & 3 & & & & & 6 \\
\hline France & 1 & 1 & & & & & 3 & 1 & & & & & 6 \\
\hline Austria & & & & & & & 3 & 2 & & & & & 5 \\
\hline Belgium & & & & & & 2 & & & & 1 & 1 & & 4 \\
\hline Spain & & 2 & & & & & & 2 & & & & & 4 \\
\hline Hungary & & & & & & & & 2 & & & & & 3 \\
\hline Germany & & & & 2 & & & & 1 & & 1 & & & 3 \\
\hline Netherlands & 2 & & & & & & & & & & & & 2 \\
\hline Italy & & & & 1 & & & & & & & & & 1 \\
\hline Totals & 22 & 4 & 13 & 34 & 1 & 105 & 28 & 77 & 2 & 9 & 9 & 9 & 313 \\
\hline
\end{tabular}

